\title{
STAKEHOLDER CONFLICTS IN THE TIVOLI, ROŽNIK HILL, AND ŠIŠKKA HILL PROTECTED LANDSCAPE AREA
}

Aleš Smrekar, Mateja Šmid Hribar, Bojan Erhartič $\dagger$

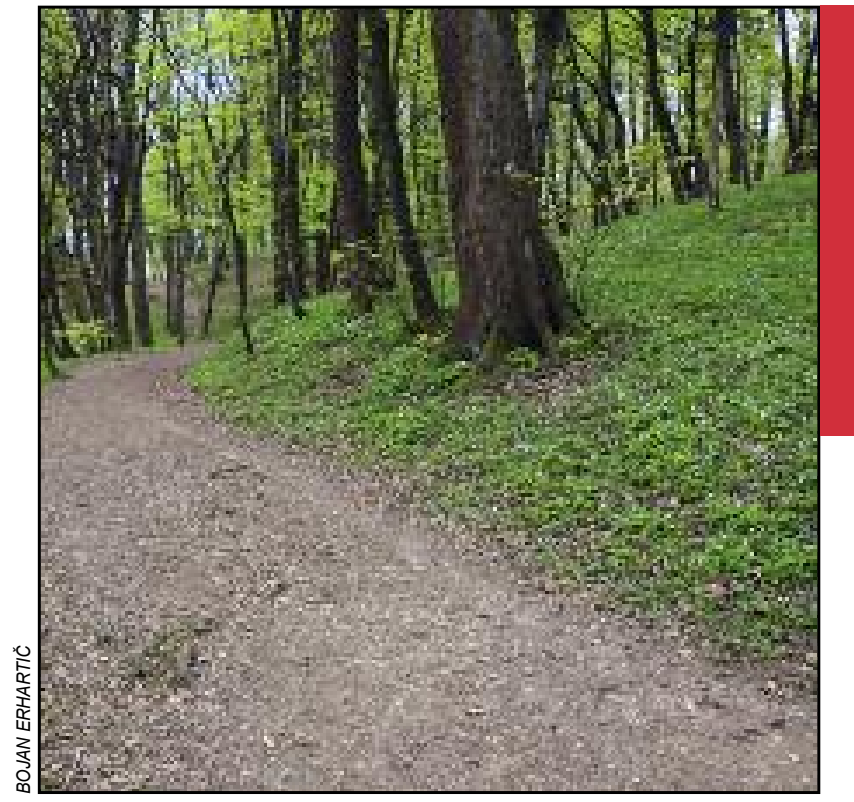

Forest forms the central part of the park. 


\section{Stakeholder conflicts in the Tivoli, Rožnik Hill, and Šiška Hill Protected Landscape Area}

DOI: http://dx.doi.org/10.3986/AGS.895

UDC: $911.53: 502.1(497.4$ Ljubljana)

COBISS: 1.01

ABSTRACT: Green areas and especially their distribution and composition are the key factor that makes urban people's lives more comfortable and healthier. Even though Ljubljana residents also have many other green areas at their disposal in their immediate vicinity, the area of Rožnik Hill and Tivoli Park as an urban forest with dispersed park features continues to be the most popular recreational destination, with roughly 1,750,000 visits per year. In 1984 it was designated a protected landscape area through an ordinance. In the past decades, a number of conflicts have arisen in this area between various stakeholders, such as landowners, park users, and specialist services, which is why these types of areas require careful and prudent management.

KEY WORDS: geography, protected area, protected landscape area, management, green areas, urban forest, Ljubljana

The article was submitted for publication on July $24^{\text {th }}, 2014$.

ADDRESSES:

Aleš Smrekar, Ph.D.

Anton Melik Geographical Institute

Research Center of the Slovenian Academy of Sciences and Arts

Novi trg 2, SI - 1000 Ljubljana, Slovenia

E-mail: ales.smrekar@zrc-sazu.si

Mateja Šmid Hribar, Ph.D.

Anton Melik Geographical Institute

Research Center of the Slovenian Academy of Sciences and Arts

Novi trg 2, SI - 1000 Ljubljana, Slovenia

E-mail: mateja.smid@zrc-sazu.si

Bojan Erhartič $†$ Ph.D.

Anton Melik Geographical Institute

Research Center of the Slovenian Academy of Sciences and Arts

Novi trg 2, SI - 1000 Ljubljana, Slovenia 


\section{Introduction}

Cities are areas of large concentrations of people and economic activities, serving as transportation hubs, centers of a creative environment, and drivers of development for the surrounding countryside, as well as centers of economic, social, and cultural life (Ravbar, Bole and Nared 2005; Kozina 2010). All of these activities, which typically shape urban areas, influence the quality of the urban living environment. Outdoor recreation largely takes place in interconnected natural and manmade green areas. They are ascribed the role of identity bearers, which is ensured through planning spatial development and setting up and maintaining the urban green areas. In addition to important ecosystem services such as air and water purification, wind and noise filtering, or microclimate stabilization, natural areas provide social and psychological services, which are of crucial significance for the livability of modern cities and the wellbeing of urban dwellers (Chiesura 2004). There is strong evidence that parks have the positive impacts on : 1) biodiversity; 2) property prices; 3 ) physical activity and reduced obesity; and 4) local cooling (Konijnendijk et al. 2013). A park experience may reduce stress (Ulrich 1981), enhance contemplativeness, rejuvenate city dwellers, and provide a sense of peacefulness and tranquility (Kaplan 1983). Local communities often overlook green areas or only become aware of their significance when they are insufficient because their primary role is recreational rather than economic.

In the City of Ljubljana, which has an area of $275 \mathrm{~km}^{2}$ and a population of approximately 280,000 (Internet 1), residents have relatively convenient access to green areas, including urban forest. The bases of Ljubljana's green system are formed by the green areas that extend into the city center and are complemented by marked circular and transverse connections and a point network of public parks. Many people use them every day and hence it is vital to include this area in the framework of the long-term vision of harmonizing the needs and demands of visitors, city dwellers, and owners (Žižek 2010). A forest is a meeting place of various interests that serves several purposes. Human needs and demands in relation to a forest change faster than the forest. A forest can be merely a recreational area, or first and foremost the main element of a recreational experience (Anko 1990). Recreation in forest does not include a single activity and is not uniform; it is a series of activities, the goal of which is to replenish people's physical and mental strength by enabling them to escape an overburdened environment, and seek a primal state and contact with nature. People usually make brief visits to the forest, but the frequency of their visits is relatively high; most importantly, Slovenian forests can be visited practically for free throughout the year (Anko 1990). A study of urban forests in various European cities highlighted four types, in which Ljubljana was mentioned as a good example in connection with two of them (Pauleit et al. 2005):

- Closed woodland surrounding the city (Oslo - Norway, Ljubljana - Slovenia);

- Woodland islands and belts within the city (Ljubljana - Slovenia, Munich - Germany);

- Dispersed woodland within an urban matrix (Black Country, United Kingdom);

- Small woodland areas in parks and gardens within the city; dispersed woodland in an agricultural matrix around the city (Florence - Italy).

As an urban forest with dispersed park features west of Ljubljana's center, the Tivoli, Rožnik Hill, and Šiška Hill area occupies a special place among the city's green areas. This article evaluates this area from the viewpoint of key stakeholders and features, and it outlines guidelines for future development.

\section{Methods}

The following methods were used in the study, which was conducted from July 2009 to September 2010:

- studying and analyzing literature, secondary sources, and legislation, collecting available databases, and preparing materials for fieldwork;

- fieldwork: counting visitors (on three Sundays and three weekdays at various times of the year);

- surveying visitors and residents about the park and parking (150 surveys; half among visitors and the rest on Prešeren Square in downtown Ljubljana among random residents that had lived in Ljubljana for at least one year);

- structured interviews for various target audiences: twenty interviews with experts in various fields (forestry, geography, architecture, sociology, and ethnology), representatives of various institutions (the Slovenian Forest Service, the Institute of the Republic of Slovenia for Nature Conservation, the Slovenian Institute for the Protection of Cultural Heritage, the Ljubljana Zoo, the University of Ljubljana's Botanical Gardens, the Tivoli Sports Recreational Center, and the City of Ljubljana), landowners, park residents, and representatives of civil society initiatives;

- data analysis and spatial display in the geographic information system. 


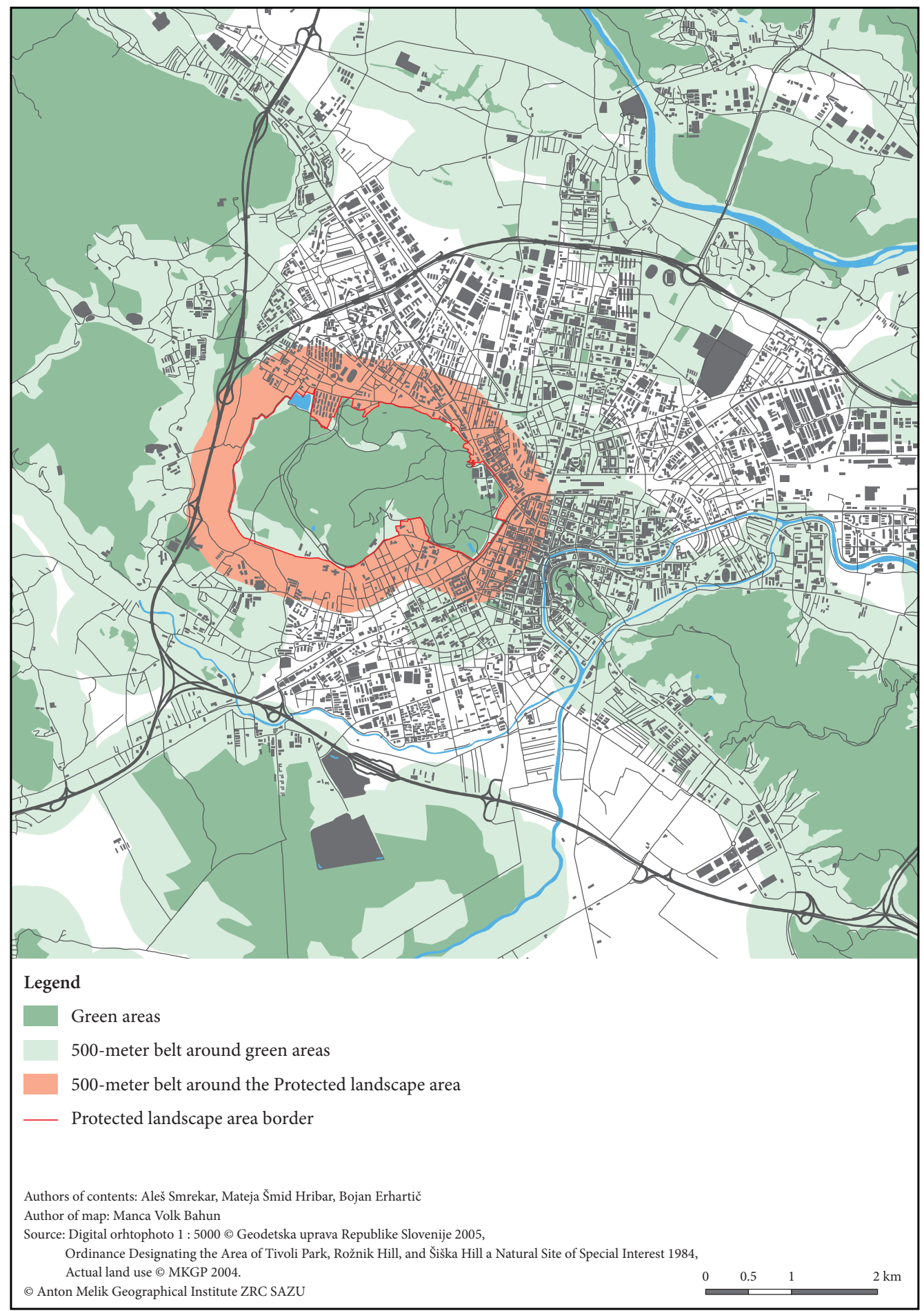

Figure 1: Green area accessibility in Ljubljana. 


\section{Outline of the park and its main stakeholders}

With a total area of 459 hectares, the Tivoli, Rožnik Hill, and Šiška Hill Protected Landscape Area extends across the northwestern edges of Ljubljana. The eastern part of this large park is covered by Tivoli Park, which is a good example of a designed natural area. Tivoli Park rises gently $130 \mathrm{~m}$ above the surrounding landscape to the top of forested Rožnik Hill and is the central part of the larger park area. Its western part is flat and lower, mostly wooded, with scattered open spaces. The western border of the park mostly runs along the thirty-kilometer long recreational trail around Ljubljana known as the »Path of Remembrance and Comradeship«, which has strong cultural and historical associations (Kranjc, Simoneti and Vidic 2006).

In 1984, the Ordinance Designating the Area of Tivoli Park, Rožnik Hill, and Šiška Hill a Natural Site of Special Interest proclaimed this area a protected landscape area »that represents the unique identity of the city of Ljubljana, where natural and cultural elements are combined into a uniform cultural and landscape area« (Odlok o razglasitvi Tivolija ... 1984). Judging from Article 2 of this ordinance, the area was designated as such for both natural and cultural reasons. In addition, the protected landscape area also includes other types of protected areas.

Despite the vicinity of the city center, its densely built-up surroundings, and a large number of visitors, the park has great biodiversity. Its hilly part is mostly covered in wild forest flora composed of acidophilous sessile oak and chestnut forests, beech forest with hard-fern, and pine forest with blueberries (Jogan 2003). An aerial photo analysis showed that forest covers 341 hectares or $74 \%$ of the park. In its central part its share is significantly higher than that (i.e., $92 \%$ ). Over four hundred plant species have been identified across the entire park (Jogan 2003). The diverse mix of bird species is another important element of this area (DOPPS 2005, cited in Načrt upravljanja ... 2008). The main reasons for such great diversity are the diverse habitat types: forest with various combinations of deciduous and coniferous trees and a large share of old trees, a park, water areas, and an urban environment.

The park does not contain any major densely built-up settlements or business organizations whose operation would depend on exploiting natural resources. A considerable portion of its southern part is taken up by the dispersed complex of research and educational institutions belonging to the emerging Biological Center (Butina 2009).

Several facilities can be found in its central wooded area at Mostec, where there are ski-jumping hills, jogging trails, and places for socializing as part of the Mostec Sports and Recreation Center. There is a catchwater on nearby peak.

The majority of trails can be found in Tivoli Park and in the wooded part of the larger park area above it. The central park in the protected landscape area has a total of approximately $85 \mathrm{~km}$ of trails, which corresponds to nearly 300 meters per hectare. The central area has no asphalted or other paved trails.

During the twentieth century, various sports and leisure facilities were introduced to Tivoli Park, which contains over eighty tree species. Tivoli Hall, built in 1965, is the largest recreation complex in the park (Internet 2). Other facilities include the tower of the former ski jumping hill on Galle Hill (Galetovo), the military installation at the top of Šiška Hill, numerous air-raid shelters, and the catchwater on Tivoli Peak (Tivolski vrh; Načrt upravljanja ... 2008).

There are approximately thirty cultural heritage sites in the park. The Register of Immovable Cultural Heritage treats the wooded part of this area as a cultural landscape and Tivoli Park as a garden-architecture heritage site. In addition, the status of a cultural heritage site has been conferred on Cekin Castle and its park, Tivoli Castle, Tivoli Hotel (also known as 'the Swiss House' (Švicarija)), the former open-air theater behind Tivoli Castle, and approximately fifteen statues, monuments, and memorial plaques (Register nepremične ... 2010).

Ten information boards with a map of the park can be found at highly frequented locations, informing visitors about the special features, characteristics, and values of the protected landscape area.

\subsection{Landowners}

According to Zadravec (2004), 56\% of the forested land on Rožnik Hill is privately owned. It is divided between approximately 340 owners, a full half of whom do not manage the forest. Based on the surveys conducted among them, Zadravec established that only a tenth of respondents receive some kind of income from the forest. Half of the owners are over sixty years old and almost all of them (i.e., 97\%) inherited wooded land 


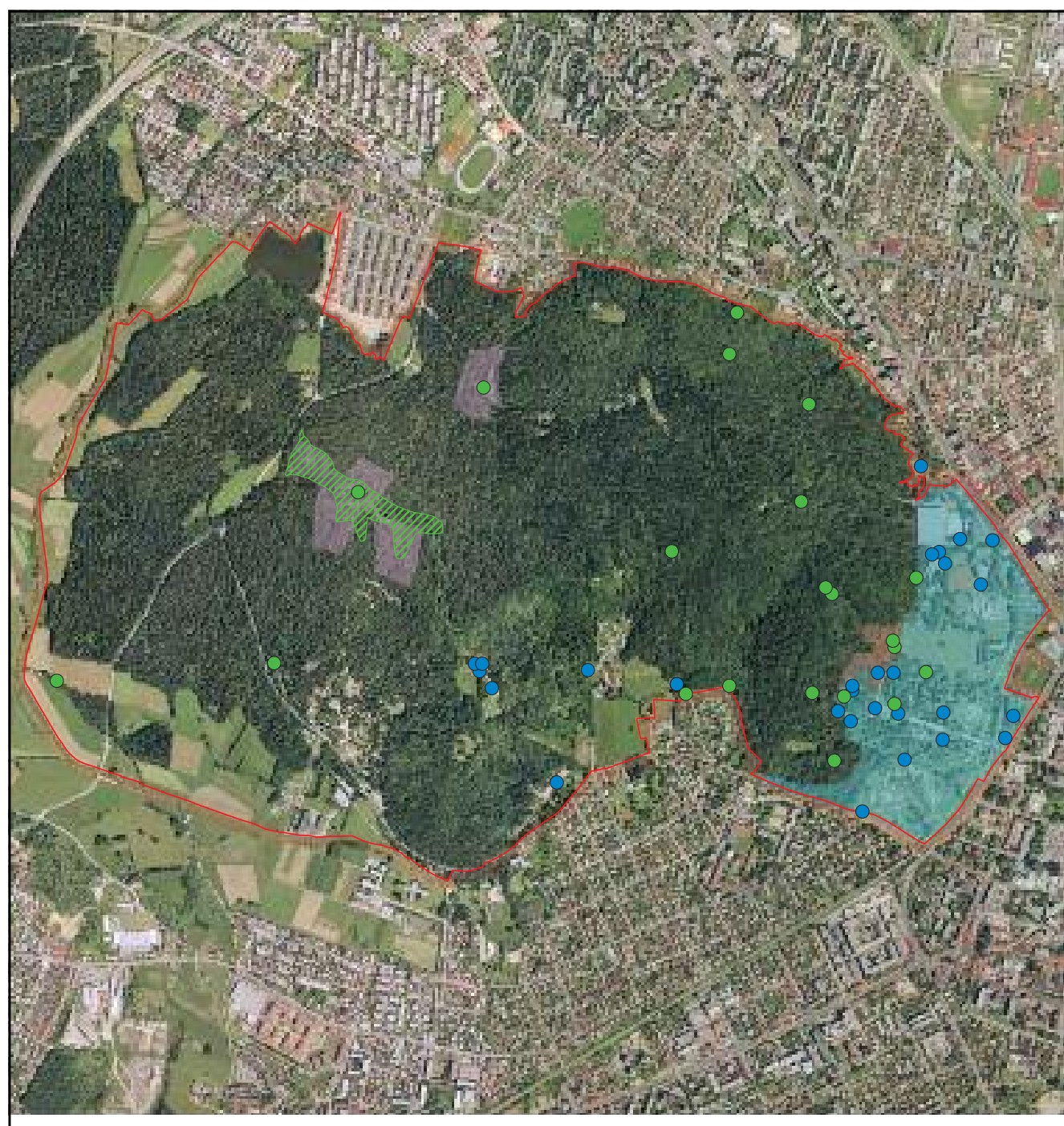

Legend
Nature reserve
- Natural value
Natural monument
- Cultural heritage
Designed natural area
$\longrightarrow$ Protected landscape area border
Ula Natural value

Authors of contents: Aleš Smrekar, Mateja Šmid Hribar, Bojan Erhartič

Author of map: Manca Volk Bahun

Source: Digital orthophoto $1: 1000$ @ Geodetska uprava Republike Slovenije 2005, Ordinance Designating the Area of Tivoli Park, Rožnik Hill, and Šiška Hill a Natural Site of Special Interest 1984. (C) Anton Melik Geographical Institute ZRC SAZU

Figure 2: Main parts of the protected landscape area. 


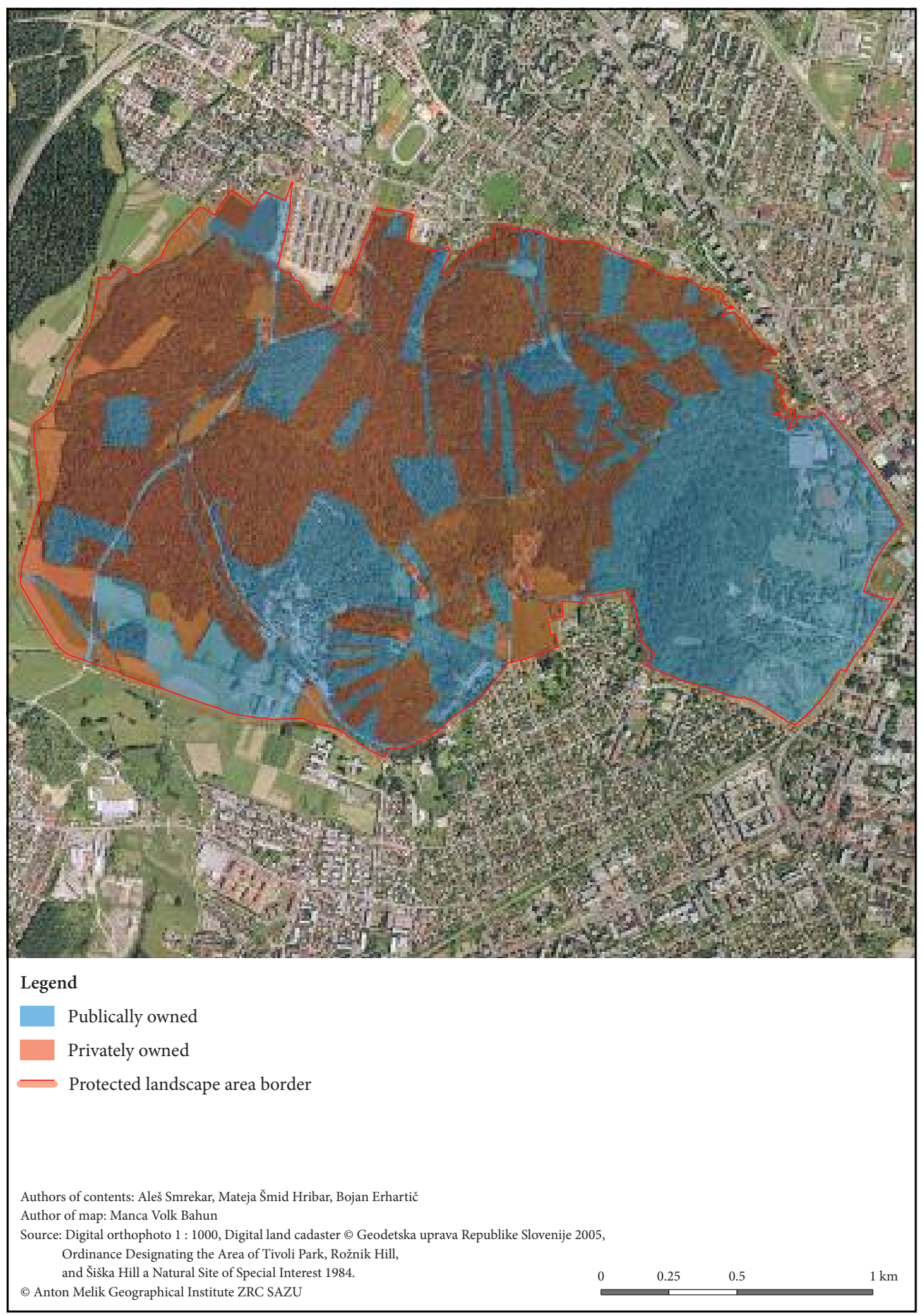

Figure 3: Land ownership in the park 
on Rožnik Hill. The wooded lots are small and very fragmented: two-thirds of owners own less than one hectare of forest, just under a third own one to five hectares, and just under a fifth of them own more than five hectares. Just under half of the owners live in the immediate vicinity of the park, and two-fifths visit the woods at Rožnik very rarely (i.e., only a couple of times a year or never). Logging is carried out by $16 \%$ of the owners, and clean-up logging by $29 \%$. Their most frequent reasons for not logging are not being qualified for it (37\%), not being physically able to do it (24\%), and the fact that logging is not economically attractive to them (22\%; Zadravec 2004).

Recently several major owners have performed clean-up logging in their forested land in line with a decree from the Ljubljana Unit of the Slovenian Forest Service (Čad 2010). The owners of smaller patches of forest usually do not take care of them and accordingly also do not carry out maintenance work and clean-up logging. The owners are very displeased with the current situation, as shown by their comments: „Ljubljana residents think everything belongs to the city and are unaware that this is private property; as the owner I'm paying for other people's recreation « (Babnik 2010); »... we owners are protecting our interests, which means we're restricting movement and use (Čad 2010). According to Zadravec's findings (2004), forest owners highlight the improper behavior by visitors. Čampa (1993) established that vandalism, recreation, disrespect for property, and motor vehicles are the most problematic.

\subsection{Visitors}

Compared to landowners, visitors are a larger group of the park users. Because there are no official data on or estimates of how many people visit the Tivoli, Rožnik Hill, and Šiška Hill Protected Landscape Area on a daily or annual basis, this information was obtained by counting visitors in 2009 and 2010.

Table 1: Visits to the park area at individual counting points.

\begin{tabular}{|c|c|c|c|c|c|c|c|c|c|}
\hline \multirow[t]{2}{*}{ Counting Point } & \multicolumn{3}{|c|}{ Fall (September 2009) } & \multicolumn{3}{|c|}{ Winter (January 2010) } & \multicolumn{3}{|c|}{ Spring (May 2010) } \\
\hline & Entry & Crossing & Total & Entry & Crossing & Total & Entry & Crossing & Total \\
\hline 1 & 833 & - & 833 & 935 & - & 935 & 1,199 & - & 1,199 \\
\hline 2 & - & 925 & 925 & - & 471 & 471 & - & 1,352 & 1,352 \\
\hline 3 & 1,196 & - & 1,196 & 875 & - & 875 & 1,370 & - & 1,370 \\
\hline 4 & 548 & - & 548 & 634 & - & 634 & 634 & - & 634 \\
\hline 5 & 2,144 & - & 2,144 & 1,064 & - & 1,064 & 2,586 & - & 2,586 \\
\hline 6 & 882 & - & 882 & 719 & - & 719 & 918 & - & 918 \\
\hline 7 & - & 1,414 & 1,414 & - & 1,207 & 1,207 & - & 2,010 & 2,010 \\
\hline 8 & - & 2,027 & 2,027 & - & 1,283 & 1,283 & - & 2,934 & 2,934 \\
\hline 9 & - & 2,114 & 2,114 & - & 1,868 & 1,868 & - & 2,278 & 2,278 \\
\hline 10 & - & - & - & - & - & - & 2,289 & - & 2,289 \\
\hline 11 & - & - & - & - & - & - & 1,461 & - & 1,461 \\
\hline 12 & - & - & - & - & - & - & 389 & - & 389 \\
\hline 13 & - & - & - & - & - & - & 329 & - & 329 \\
\hline 14 & - & - & - & - & - & - & 1,033 & - & 1,033 \\
\hline 15 & - & - & - & - & - & - & 1,616 & - & 1,616 \\
\hline 16 & - & - & - & - & - & - & 396 & - & 396 \\
\hline 17 & - & - & - & - & - & - & 135 & - & 135 \\
\hline 18 & - & - & - & - & - & - & 502 & - & 502 \\
\hline Total & 5,603 & 6,480 & 12,083 & 4,227 & 4,829 & 9,056 & 14,857 & 8,574 & 23,431 \\
\hline
\end{tabular}

The majority of visitors (44\%) were fifteen to thirty-five years old, followed by those thirty-six to sixty-five years old (36\%), and people over sixty-five (6\%).

Like the majority of outdoor recreational activities, visits to the park also have two annual peaks, one in the spring and one in the fall. The number of visits is smaller in the summer because of the heat and summer vacations, and in the winter because of the low temperatures and short days. The number of people visiting the area during the week is three times smaller than on Sundays, which can be ascribed to work and other obligations. Based on the counts, it can be estimated that during weekdays the park is visited 


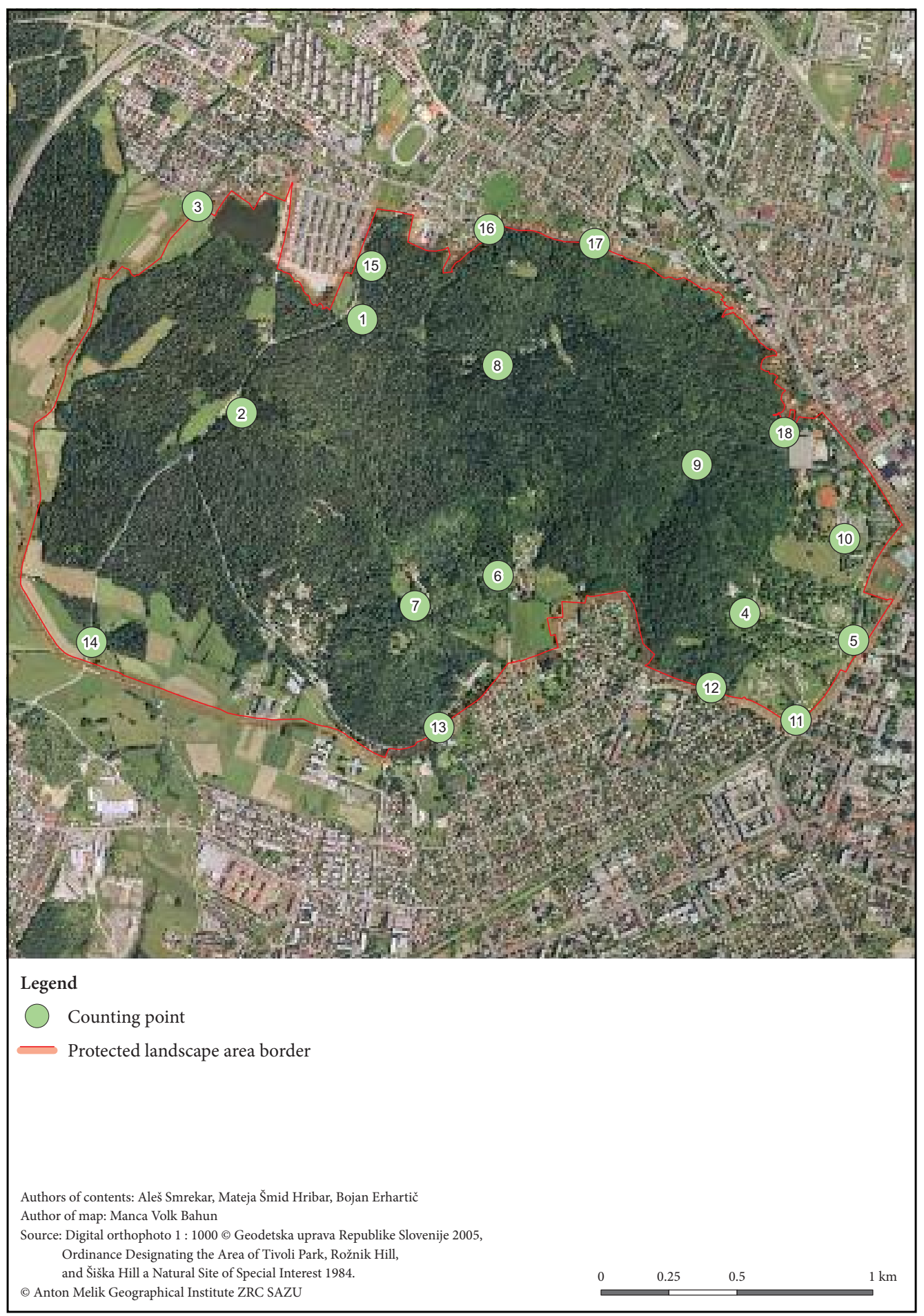

Figure 4: Points for counting visitors in the park. 
by an average of 3,500 people, on Sundays in winter by 6,000 people, on Sundays at other times of the year by approximately 9,500 people, and on the most pleasant days off work by approximately as many as 20,000. A field inspection showed that the number of Saturday visits is approximately $25 \%$ less than the number of Sunday visits. Based on multiple counts, observations, and calculations, we estimate that approximately 1,750,000 people visit the Tivoli, Rožnik Hill, and Šiška Hill Protected Landscape Area annually. However, this number does not include special events (i.e., the May Day celebration on Rožnik Hill, a large number of gatherings at the Mostec area, and the large sports and entertainment events held at Tivoli Hall), visitors to the ZOO and Tivoli Hall, and parking area users (Smrekar, Erhartič and Šmid Hribar 2011). The daily rhythm of weekend visits shows that visitors come in two waves: in the morning between 10:30 and 12:30, and in the afternoon between 3:30 and 5:00 (in the spring even as late as 6 pm). During the week, people tend to visit the area mainly in the afternoons.

The majority of visitors enter the area from the city center. They enter the central, wooded part of the park through Tivoli Park and the Mostec area. Many of them also use part of the Path of Remembrance and Comradeship. The main type of recreation in the area is hiking (73\%), followed by cycling (13\%) and jogging (7\%). A smaller share of respondents also use the forest to walk their dogs and other pets, date, attend large-scale events, feed the birds, gather berries and nuts, visit exhibitions or museums, and to visit the local restaurants.

The inventory also showed the most common forms of socializing. This depends on the dynamics, behavioral characteristics, infrastructure needs, and (in)compatibility of different recreation (Anko 1987). The inventory of visitors revealed that a quarter of visitors come to the park alone, a quarter come with their partner, a quarter with their families, $18 \%$ with a friend, and $7 \%$ as part of a large group.

The survey showed that Tivoli Park and the wooded area are similar in terms of the average time visitors spend there; visitors tend to linger only slightly longer in the central wooded area. The majority of those visiting these two areas (i.e., 37\%) stay there just under an hour (41 to 60 minutes), followed by those that visit the area for 21 to 40 minutes, and finally, those that leave the area in less than twenty minutes. Only a few people stay in the park for more than two hours, which confirms the assumption that the area is mostly a recreational place where visitors go for a quick rest.

Even though the visitors live fairly close to the area, a full $45 \%$ of the respondents go there by car or motorcycle, $27 \%$ walk, $18 \%$ come by bike, and only $10 \%$ use public transport. Regardless of the means of transport used, the majority of visitors surveyed need sixteen to thirty minutes to get to the park from their homes, $36 \%$ get there in six to fifteen minutes, and 5\% live less than six minutes away. Sixteen percent of the respondents need more than half an hour to reach the area.

\section{The park as a value}

One of the starting points of our research was to examine whether the Tivoli, Rožnik Hill, and Šiška Hill Protected Landscape Area is considered a value and, if so, what kind of value. The park is definitely very important for Ljubliana residents because it offers them diverse ways of experiencing the natural environment and an opportunity to relax psychologically and exercise outdoors. Judging from the opinions expressed in the interviews, we can conclude that the area is a value that needs to be protected.

The key value of the area studied is the immediate vicinity of the natural environment ( 341 hectares of forest and 43 hectares of Tivoli Park as an example of a planned natural area), which is freely accessible to numerous Ljubljana residents and visitors. According to Torelli (2010), this kind of harmony between the city and the forest, in which the city changes into a conserved forest via a designed park, is difficult to find in other comparable European cities. In Ljubljana, one can walk in less than fifteen minutes from one edge of the forest to another through the city center (Rožič 2010).

This fact places the recreational and social aspects that contribute significantly to the wellbeing in the city at the forefront (Pirnat 2010; Pergovnik Cotič 2010). In 1860, when Ljubljana Mayor Etbin Henrik Costa bought Tivoli Castle, Tivoli Park was described in the newspapers as »the most beautiful place in Ljubljana." This certainly attests that the area studied, and especially Tivoli Castle and its surroundings, was once considered an aesthetic value among the city's residents (Ovsec 1994). In addition, ecological and ecosystem aspects also stand out in the park. It is completely understandable that in this type of environment economic aspects are pushed into the background. The multifaceted nature of the urban forest, 


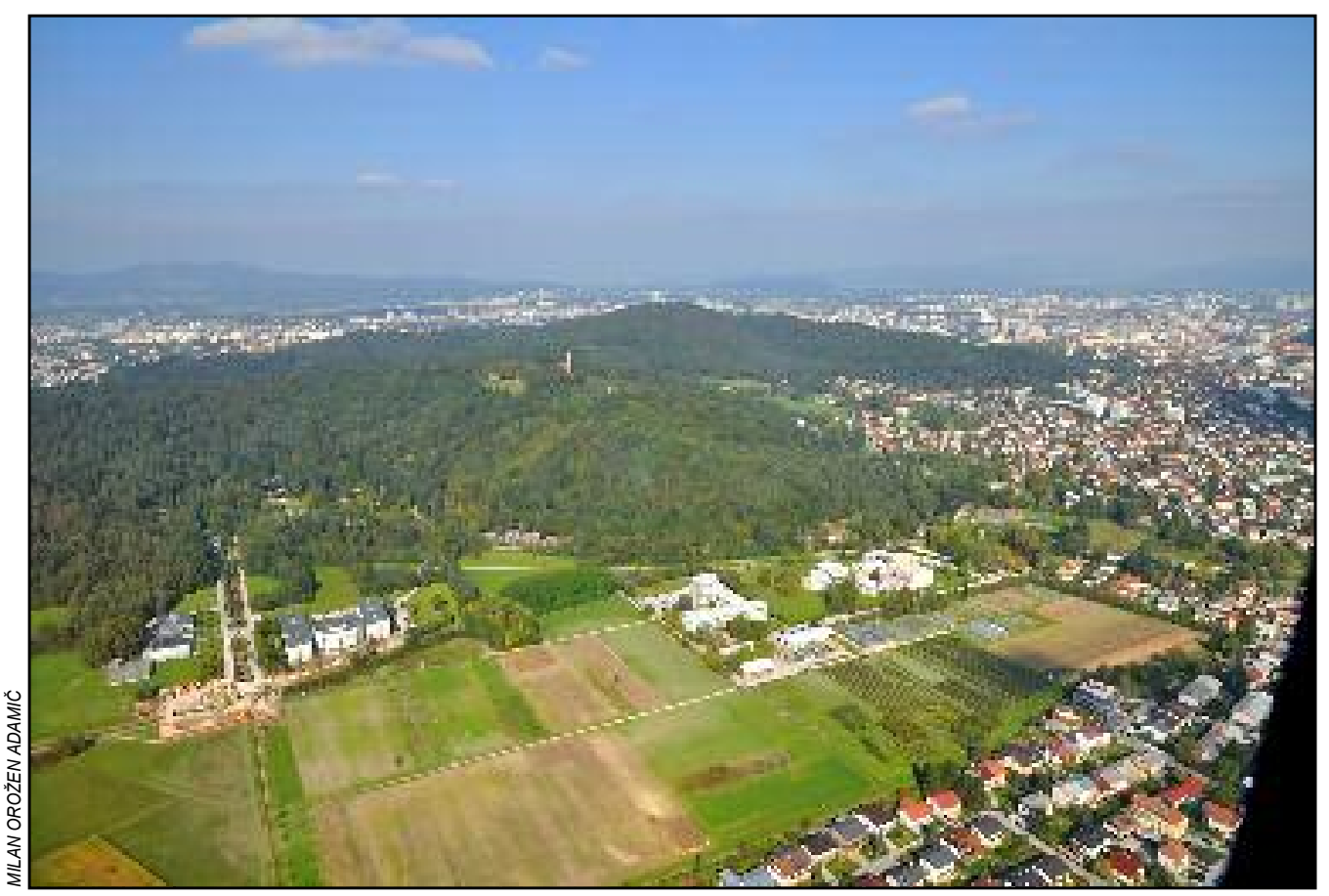

Figure 5: The city extending into the park.

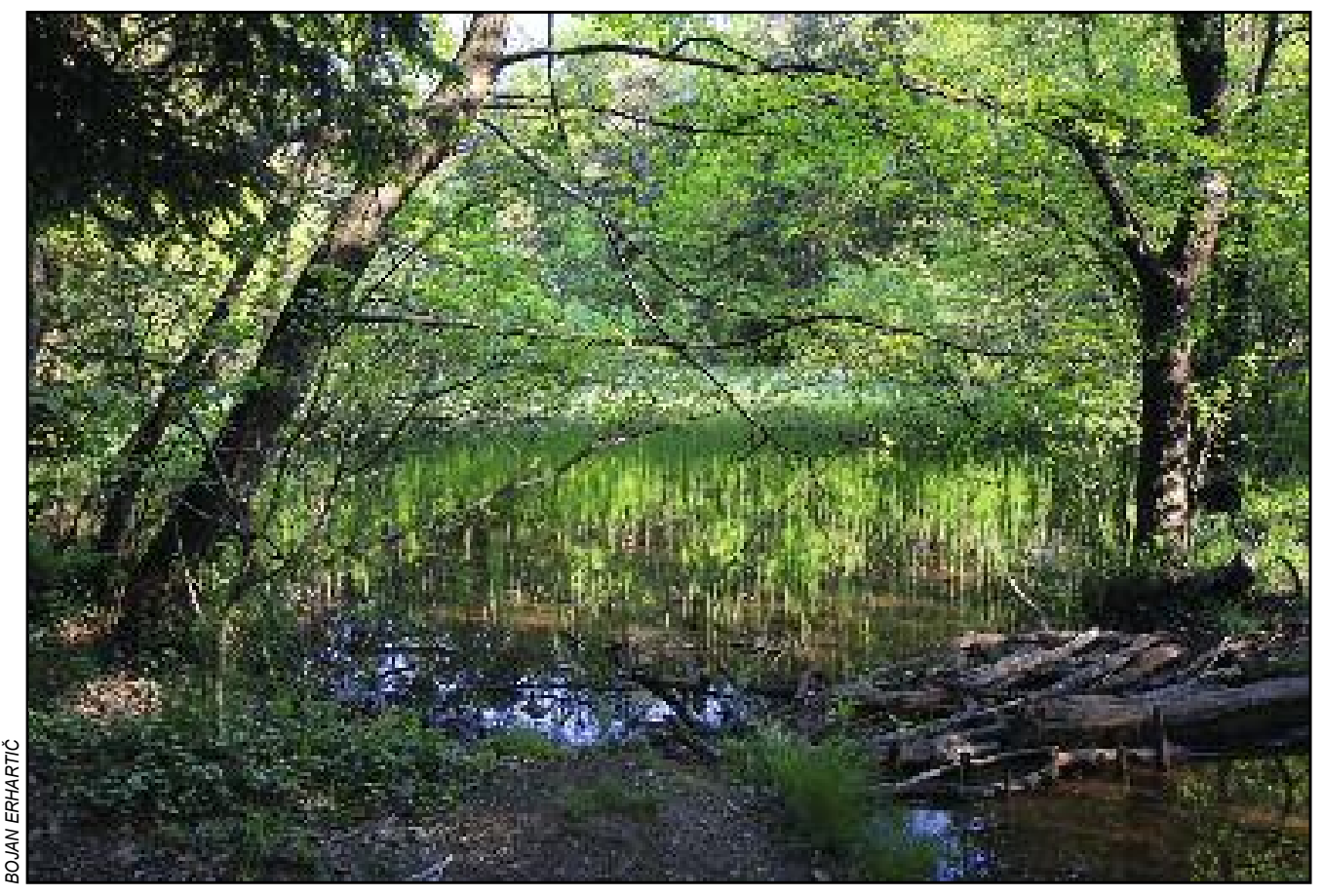

Figure 6: The Little Rožnik Hill Nature Reserve. 
which is simultaneously a natural and cultural heritage site, should also be taken into account in the management of the park.

Another value, which may not seem as obvious at first glance, is the area's natural endowment with water (Jerman 2010; Rožič 2010). Rožnik and Šiška hills have a number of springs. It is no coincidence that the path from Bellevue Hotel to Tivoli Hotel is referred to as the »Trail of Seven Footbridges (Jerman 2010; Rožič 2010), and that a kneipp-spa operated near the Čad Inn at the beginning of the twentieth century (Ovsec 1994; Torelli 2010).

Torelli (2010) also drew attention to the museological and educational value of the area, which makes it possible to experience the forest as a live museum. This also includes the unmaintained section of the forest or the "urban wild, " and thus not only the designed park, but also the forest, where one can see wild animals. Parks are usually a common feature in capital cities, whereas a wild forest in the direct vicinity of the city center is more of a rarity (Kurinčič Mikuž 2010; Kranjec Menaše 2010).

\section{Discussion}

The analysis shows that the entire park is divided into three distinct parts: the smaller designed park (Tivoli), the wooded part (Rožnik and Šiška hills), and the green areas between the Koseze and Brdo neighborhoods. Each of them has its own typical features and offers a different way of experiencing the natural environment and spending free time. All three parts must be viewed as a complementary whole because the interconnection of various places are important not only for people, but also for plants and animals, presents a unique added value for them. This is what distinguishes this area significantly from other green areas found in other major European cities.

Hiking is the most frequent type of recreation. Because of the large number of people visiting the park (up to 20,000 visitors a day and roughly 1,750,000 visitors a year), conflicts arise between landowners, visitors, and the objectives of natural and cultural heritage conservation (Odlok o razglasitvi Tivolija ... 1984). In order to prevent conflicts, activities that are in line with the conservation objectives of the park must be clearly highlighted, and land ownership must be regulated to avoid dissatisfaction among both owners and visitors. Because of unregulated ownership, the forest represents a burden to the owners or, as highlighted by Anko (2010), "Rožnik Hill is utterly useless for an owner, but an ideal thing for the city dweller. "The best solution would be to purchase the private land in the park. A step in this direction has already been made with the adoption of the Ordinance Designating Special-Purpose Forests (2010). According to this ordinance, the owners of wooded plots are entitled to tax relief or compensation and, if an owner so requests, the City of Ljubljana is obligated to purchase his wooded land.

Without a common long-term vision combining development and protection, the vested interests of the landowners, the municipality, and visitors result in spontaneous development, which usually increases the dissatisfaction among all stakeholders. The area is currently quite neglected and in many places also degraded. The municipality must assume the key role in seeking joint solutions. Overall development should proceed from the assumption that the area is a green oasis in the middle of an urban environment, in which residents can relax and experience the natural environment (Pergovnik Cotič 2010).

However, after nearly twenty-five years the park still does not have a manager to take care of the numerous aspects of the protected area. In addition, zoning of the area is vital, with a suitable distribution of activities. The forest covers a full $74 \%$ of the protected area. Because this is an urban forest, its management should focus on seeking a balance between ecological and social functions.

The area has various categories of trails. The most problematic are the muddy unmaintained tracks, crisscrossing one another and subject to erosion (Verlič et al. 2015). Therefore, some of these tracks should be closed to visitors and some should be converted into trails, to which visitors (who now walk wherever they want) could be diverted. This would move people away from some areas to areas intended for recreation.

\section{Conclusion}

A high-quality living environment is an exceptionally important life value of modern urban life, and green areas are one of its key factors. One of the largest and most popular green areas in Ljubljana is the Tivoli, Rožnik Hill, and Šiška Hill Protected Landscape Area. 


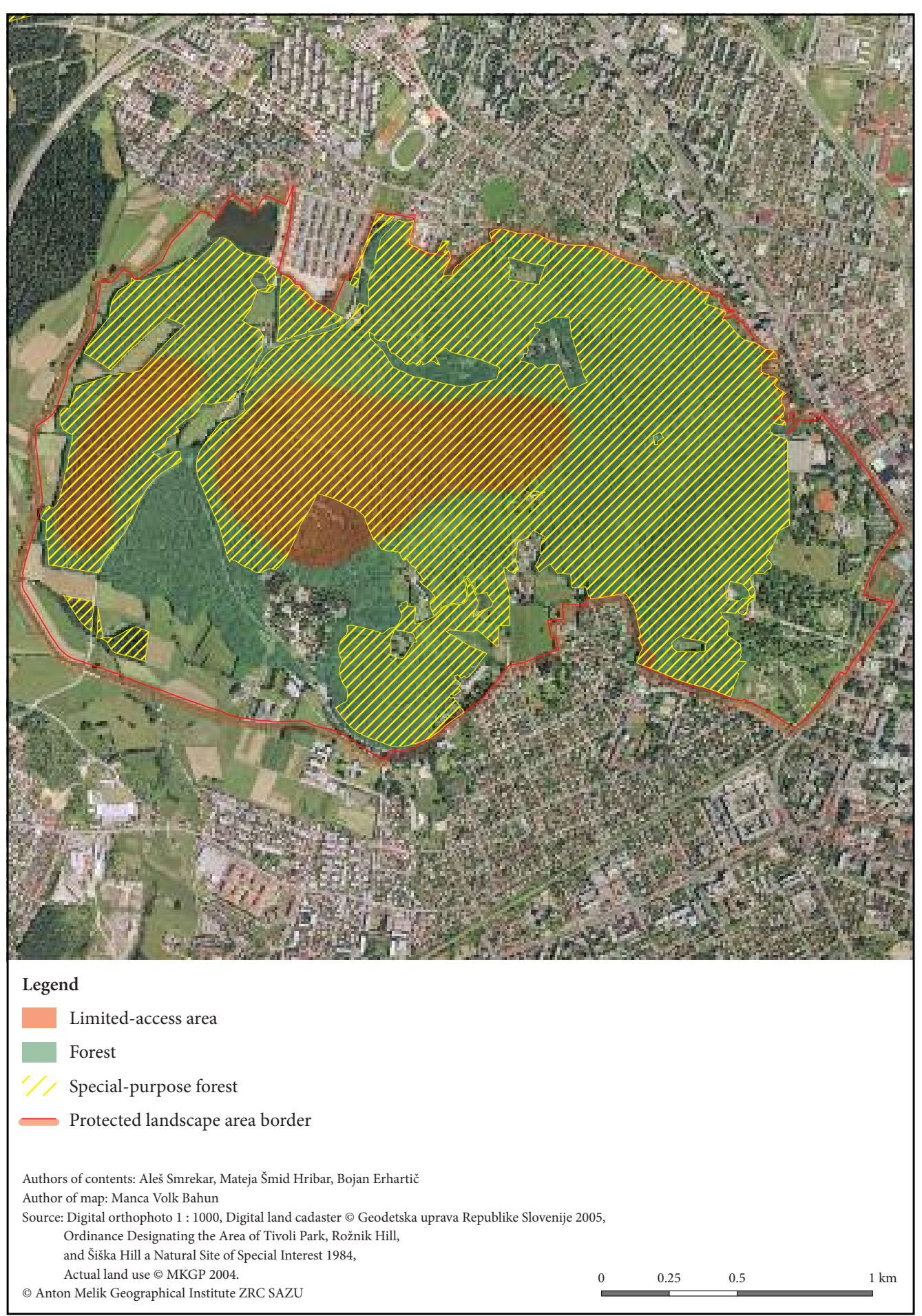

Figure 7: Redirecting visitors in the park. 
It is estimated that this protected area is annually visited by approximately $1,750,000$ people, not even counting the visitors to the ZOO and Tivoli Hall, and the users of the parking areas in Tivoli Park. The largest number of people visit the park on Sundays (i.e., up to 20,000). Visitors are usually seeking a brief break from their daily work. Such a large number of visitors to this area proves that it has very important value to visitors.

A number of interests of various stakeholders are present in this type of urban protected area, which demands comprehensive management that includes nature protection, preservation of the cultural landscape, and understanding human activities within the area, on the part of both landowners and visitors. In the case of improper management, forest owners face the most problems among the stakeholders because satisfying the interests of the general public may threaten their economic management of the forest. In addition to landowners, visitors are also affected because they are expected to use the existing trails in the urban forest. It would be most prudent for the municipality to purchase the forest land. Managing a protected landscape area urgently demands zoning with an optimal distribution of activities. In an urban forest that attracts many visitors, one must precisely define the trails for hikers, joggers, and cyclists. In conclusion, attention is drawn to the following thought by Hildebert de la Chevallerie: »it is vital for the further development of Tivoli Park to evaluate the entire area of the City of Ljubljana without delay and include [the park] as a 'green belt' in spatial planning. This task, which every generation will fulfill as its duty piece by piece, will decide on the quality of life in Ljubljana« $(1994,15)$.

ACKNOWLEDGEMENTS: This article is the result of the project »Assessing the Visitor Burden and Capacity of the Wooded Section of the Tivoli, Rožnik Hill, and Šiška Hill Protected Landscape Area« financed by the City of Ljubljana. Detailed results are presented in the volume Krajinski park Tivoli, Rožnik in Šišenski hrib (The Tivoli, Rožnik Hill, and Šiška Hill Protected Landscape Area; Smrekar, Erhartič and Šmid Hribar 2011).

\section{References}

Anko, B. 1987: Analiza nedeljskega obiska primestnega gozda na primeru Šmarne gore. Zbornik gozdarstva in lesarstva 29. Ljubljana.

Anko, B. 1990: Rekreacija, turizem, gozdarstvo. Rekreacijska vloga gozda 20. Ljubljana.

Anko, B. 2010: Intervju. Ljubljana.

Babnik, V. 2010: Intervju. Ljubljana.

Butina, V. 2009: Živalski vrt Ljubljana: jubilejni pogled v zgodovino in prihodnost. Ljubljana.

Chevallerie, H. de la 1994: Park Tivoli v evropski primerjavi. Tivoli - Ljubljanski mestni park. Ljubljana.

Chiesura, A. 2004: The role of urban parks for the sustainable city. Landscape and urban planning 68-1. DOI: http://dx.doi.org/10.1016/j.landurbplan.2003.08.003

Čad, J. 2010: Intervju. Ljubljana.

Čampa, L. 1993: Javni interes in problematika lastništva v gozdovih zelenega pasu mesta Ljubljane. Mestni in primestni gozd - naša skupna dobrina. Zbornik republiškega posvetovanja v okviru tedna gozdov. Ljubljana.

Jerman, I. 2010: Intervju. Ljubljana.

Jogan, N. 2003: Inventarizacija flore dveh zavarovanih območij na Rožniku. Poročilo. Biotehniška fakulteta Univerze v Ljubljani. Ljubljana.

Kaplan, R. 1983: The analysis of perception via preference: a strategy for studying how the environment is experienced. Landscape and urban planning 12. DOI: http://dx.doi.org/10.1016/0304-3924(85)90058-9

Konijnendijk, C. C., Annerstedt, M., Nielsen, A. B., Maruthaveeran, S. 2013: Benefits of urban parks: a systematic review. A report for IFPRA. Copenhagen, Alnarp. Internet: http://research.ku.dk/find-a-researcher/ ?pure=files\%2F44944034\%2FIfpra_park_benefits_review_final_version.pdf (15.6.2015)

Kozina, J. 2010: Transport accessibility to regional centres in Slovenia. Acta geographica Slovenica 50-2. DOI: http://dx.doi.org/10.3986/AGS50203

Kranjc, U., Simoneti, M., Vidic, L. 2006: POT, največja načrtovana javna zelena površina v Ljubljani. Raziskovalni projekt. Ljubljana.

Kranjec Menaše, J. 2010: Intervju. Ljubljana. 
Kurinčič Mikuž, S. 2010: Intervju. Ljubljana.

Internet 1: http://www.ljubljana.si/si/ljubljana (1.9.2010).

Internet 2: http://sl.wikipedia.org/wiki/Hala_Tivoli (5.8.2010).

Načrt upravljanja 2010-2020 (osnutek). Krajinski park Tivoli, Rožnik in Šišenski hrib. Ljubljana, 2008.

Odlok o razglasitvi gozdov s posebnim namenom. Uradni list Republike Slovenije 60/2010. Ljubljana.

Odlok o razglasitvi Tivolija, Rožnika in Šišenskega hriba za naravno znamenitost.

Uradna lista Socialistične Republike Slovenije 21/1984 in 47/1987. Ljubljana.

Ovsec, D. 1994: Iz življenja Tivolija skozi čas. Tivoli - Ljubljanski mestni park. Ljubljana.

Pergovnik Cotič, D. 2010: Intervju. Ljubljana.

Pauleit, S., Jones, N., Nyhuus, S., Pirnat, J., Salbitano, F. 2005: Urban forest resources in European cities. Urban forests and trees: a reference book. Berlin.

Pirnat, J. 2010: Intervju. Ljubljana.

Ravbar, M., Bole, D., Nared, J. 2005: A creative milieu and the role of geography in studying the competitiveness of cities: the case of Ljubljana. Acta geographica Slovenica 45-2. DOI: http://dx.doi.org/10.3986/AGS45201

Register nepremične kulturne dediščine. Ministrstvo za kulturo. Direktorat za kulturno dediščino. Ljubljana, 2010. Internet: http://rkd.situla.org/ (18. 8.2010).

Rožič, J. 2010: Intervju. Ljubljana.

Smrekar, A., Erhartič, B., Šmid Hribar, M. 2011: Krajinski park Tivoli, Rožnik in Šišenski hrib. Georitem 16. Ljubljana.

Torelli, N. 2010: Intervju. Ljubljana.

Ulrich R.S. 1981: Natural versus urban sciences: some psycho-physiological effects. Environmental behaviour 13. DOI: http://dx.doi.org/10.1177/0013916581135001

Verlič, A., Arnberger, A., Japelj, A., Simončič, P., Pirnat, J. 2015: Perceptions of recreational trail impacts on an urban forest walk: A controlled field experiment. Urban forestry \& urban greening 14-1. DOI: http://dx.doi.org/10.1016/j.ufug.2014.12.004

Zadravec, T. 2004: Odnos lastnikov do svoje gozdne posesti na Rožniku. Diplomsko delo. Biotehniška fakulteta Univerze v Ljubljani. Ljubljana.

Žižek, L. 2010: Odnos javnosti do gozdov v mestih na primerih Rožnika in Golovca v Ljubljani. Diplomsko delo. Biotehniška fakulteta Univerze v Ljubljani. Ljubljana. 
